\title{
New North American Diptera.
}

By W. R. Walton, Bureau of Entomology,

\author{
Washington, D. C.*
}

Agromyza davisii n. sp. (Agromyzidak).

Length $2 \mathrm{~mm}$. Front, cheeks and proboscis yellow. Antennae, palpi, occiput and ocellar triangle black. Thoracic dorsum, scutellum and pleurae opaque blackish, strongly bristled. A line over the mesopleura pale yellow. Abdomen black, somewhat shining, sutures pale greenish yellow. Genitalia shining black. Legs and feet entirely black. Squamae, halteres and bases of wings yellow.

This species belongs to Meigen's group "C" (c) in which the cross veins are approximated and confined to the basal fourth of the wing, front yellow.

Described from two specimens, male and female, reared from the leaves of Ranunculus abortivus, in which it mines, by J. J. Davis, Lafayette, Indiana, and in honor of whom it is named.

Type deposited in U. S. Nat. Museum, Washington, D. C.

Microdon craigheadii sp. nov. (SyrphidAE)

Microdon laetus Walton (not Loew), Ent. News, XXII, p. 3I9, I9I I.

In Vol. xxii, p. 3I9, of Entomological News the author published a note on Microdon laetus Loew. Additional material has since been received and in going over this, in comparison with a specimen in the U. S. National Museum which is labelled " $M$. laevis Loew," the two forms are evidently abundantly distinct. Now as there is no such species as " $M$. laevis Loew," and as the specimen referred to above agrees closely with Loew's description of laetus and is furthermore from Cuba, the type locality of laetus, it becomes obvious that the Pennsylvania specimens constitute a new species to which the name Microdon craigheadii is herewith given. To the previous description (l. c., p. 320), the following details may be added:

Male.-Head about as wide as thorax, face three-quarters as wide as eye; eyes nearly bare.

*Published by permission of Chief of Bureau. 
Female.-Cross veins slightly infuscated. Length II-I2 $\mathrm{mm}$.

Type.-One specimen, Carlisle Junction, Pa., F. Craighead.

Paratypes.-One specimen, Enola, Pa., H. F. Adams. Rockville, $\mathrm{Pa}$.; one specimen by author, others by $\mathrm{A}$. B. Champlain.

Type in U. S. Nat. Museum, Washington, D. C.

$M$. laetus Loew has distinctly hairy eyes, head wider than thorax, face not more than half as wide as either eye, abdomen more narrowed posteriorly, whole color more violaceous than $M$. craigheadii and wing veins, especially cross veins, heavily stained with brown.

\section{Fragments on North American Insects-II.}

By A. A. Girault, Nelson, Cairns, North Queensland. 1.

\section{More Notes on Estigmene acreae. (Lepid.).*}

A female of this species was captured from grass at Blacksburg, Virginia, May I6, I902, and upon rough confinement began to deposit eggs. The rate of deposit was regular, an egg being laid about every twenty seconds, or three every minute. Oviposition commenced about 3 P. M., May I6, and continued until the early morning of May I7; the total number was one thousand one hundred and twenty-nine. The eggs commenced to hatch at about $8 \mathrm{~A}$. M., May 23, 1902; two had hatched by $10 \mathrm{~A}$. M., and by the afternoon of the same day a hundred or more. Hatching was then becoming general. The eggs were deposited upon a thin network of hairs and attached by means of a yellowish-brown secretion. The first molt occurred on May 26; another on June Io, and by July 2 a few of the caterpillars had spun cocoons. At that date, however, the majority were yet feeding. By July 6 all had spun cocoons. The larvae had been fed upon wild plaintain and grasses. The adults issued the first week in August.

2. Megalopyge opercularis Smith and Abbot. (Lepid.).

On October 5, I902, larvae of this species were received from a correspondent at Lynnhaven, Princess Anne County,

*See No. 8, page 406, antea. 


\section{$2 \mathrm{BHL}$ Biodiversity Heritage Library}

1912. "New North American Diptera." Entomological news, and proceedings of the Entomological Section of the Academy of Natural Sciences of Philadelphia 23, 463-464.

View This Item Online: https://www.biodiversitylibrary.org/item/20184

Permalink: https://www.biodiversitylibrary.org/partpdf/3931

\section{Holding Institution}

Smithsonian Libraries

\section{Sponsored by}

Smithsonian

\section{Copyright \& Reuse}

Copyright Status: NOT_IN_COPYRIGHT

This document was created from content at the Biodiversity Heritage Library, the world's largest open access digital library for biodiversity literature and archives. Visit BHL at https://www.biodiversitylibrary.org. 